\title{
FACTORS INFLUENCING THE SUCCESS OF PERFORMANCE MEASUREMENT: EVIDENCE FROM LOCAL GOVERNMENT
}

\author{
Herlina Primarisanti \\ Faculty of Economics and Business, Universitas Gadjah Mada \\ (herlinaprimarisanti@yahoo.co.id) \\ Rusdi Akbar \\ Faculty of Economics and Business, Universitas Gadjah Mada \\ (rusydi.akbar@gmail.com)
}

\begin{abstract}
There were only a few government institutions in Indonesia capable of preparing good accountability reports. Based on the survey conducted in the Special District of Yogyakarta, the study aimed to empirically examine the influencing factors in the development of the measurement system of performance, performance accountability and the use of performance information. Additionally, it also tried to interpret and to explain empirical evidence in the perspective of the institutional theory. The institutional theory was used to find out the extent to which the development of the measurement system of the performance, the performance accountability and the use of the performance information was influenced because of the presence of coercive, mimetic and normative isomorphism phenomena. The study used mixed methods that combined quantitative and qualitative study approaches simultaneously and a sequential explanatory strategy. It used Partial Least Square (PLS) analysis to test the hypotheses. It gave evidence that training, incentives and authority in decision making had significant impacts on the development of the measurement of the performance, the performance accountability and the use of the performance information. It contributed to the understanding of the influencing factors of the development of the measurement system of the performance, the performance accountability and the use of the performance information in order to improve the measurement system of the performance of government institutions.
\end{abstract}

Keywords: performance measurement system, performance accountability, the used of performance information and mixed methods.

\section{INTRODUCTION}

Starting with the Presidential Instruction No. 7 of 1999 and completed by Regulation No. 29 of 2010 of the Minister for State Apparatus Utilization and Bureaucracy Reformation on the Guidelines for Framing the Determination of Performance and Reporting on the Accountability of Government Agencies which required that government institutions must prepare and present their Laporan Akuntabilitas Kinerja Instansi Pemerintah (LAKIP). However, there were in fact only a few government institutions that were able to prepare good accountability reports. The reports in general did not inform of the success of the institutions using proper performance measurements. They reported more about the activities they had organized and did not focus on the performance of the improvements which they had made (Effendy, 2006).

The issuance of the Regulation of the Minister for State Apparatus Utilization and Bureaucracy Reformation Number 29 of 2010 was indicative of the seriousness of the government in improving the performance of the government organizations in developing performance-based management of the government organizations in Indonesia. Therefore, the author was motivated to conduct a study of the measurement of the performance of government organizations, which was still relevant because the measure- 
ment of the performance of the government organizations must continuously be improved (Yowi, 2011). Additionally, there were still problems in the implementation of the existing performance measurement system, in addition to the frequent use of the implementation of the performance measurement system if it was properly implemented, the opportunity to improve the quality of the development of the performance measurement system in the future, and there have not been any studies to uncover the condition of the implementation of the performance measurement system in the government institutions of the Republic of Indonesia (Nurkhamid, 2008).

The results of the studies by (Julnes and Holzer, 2001; Cavalluzzo and Ittner, 2003; Sihaholo and Halim, 2005; Putra, 2006; Nurkhamid, 2008; Fachruzzaman and Norman, 2010; Yowi, 2011; Astuti and Adiwibowo, 2011; Akbar et al, 2012; Wijaya and Akbar, 2012) suggested that the problems in the performance measurement system occurred at the development and the implementation steps. The study used the conceptual model developed by Julnes and Holzer (2001) and Cavalluzzo and Ittner (2003) to identify the influencing factors in the development of the measurement system of performance, performance accountability, and the use of performance information using the institutional theory to explain isomorphism phenomena in local governments. Also, it used mixed methods to test the hypotheses with a Partial Least Square (PLS) analysis. Therefore, the questions of the study were as follows: what were the problems in determining performance measurement, training, top management commitment, innovation, incentive, the limitations of the information system and the authority in decision making that influenced the development of the measurement system of performance, performance accountability, and the use of performance information? Was there an isomorphism in the development of the measurement system of performance, performance accountability and the use of performance information?

The study aimed at empirically examining the influencing factors on the development of the measurement system of performance, performance accountability and the use of performance information. Additionally, it interpreted and explained empirical evidence in the perspective of institutional theory. The institutional theory was used to find out the extent to which the development of the measurement system of the performance, the performance accountability and the use of the performance information was influenced by the presence of coercive, mimetic and normative isomorphism phenomena.

It was expected that the study would contribute to the literature on the influencing factors of the measurement system of the performance, the performance accountability and the use of performance information, especially by government institutions. It was also expected that the results of the study could contribute inputs to the government institutions of Indonesia, especially the government of the Special District of Yogyakarta, that the influencing factors would be recommended to be included in the improvement and the development of the measurement system of the performance, to make it into a better and more effective one, to support decision making and to improve government performance.

\section{THEORETICAL BASIS AND HYPOTHESES DEVELOPMENT}

\section{Institutional Theory}

The institutional theory is a social theory which is focused on developing sociological insights into institutions, the way they interact and their effect on people (Scott, 1987). The institutional theory digs deeper into social structures (Scott, 2004). It has been widely used to explain phenomena and give complex and rich insights into public sector organizational environments (Van Helden, 1995 in Wijaya and Akbar, 2012).

According to Scott (1995) there were three institutional pillars, viz. regulative, normative and cognitive ones. Gudono (2012) suggested that not all experts agreed with Scott's institutional pillar. The relationship of each of the pillars, the sequence and the complementary capability of each of them also deserves attention. 
Additionally, there is a concept which it is necessary to explain, relating to the existing mechanism in the three pillars, which is the isomorphism concept (i.e., the process into the same form; iso means the same and morp means form).

DiMaggio and Powell (1983) defined isomorphism as a "constraining process" that forces a unit in a population to have the same form or characteristics as other units facing the same environmental condition. The isomorphism is classified into two, viz. competitive and institutional ones. The competitive isomorphism is the most relevant to open competition, while the institutional isomorphism fits the situation in which no free competition exists. It is because organizations not only compete for resources or consumers, but also for institutional or political legitimacy. Public organizations are more likely to gain their legitimacy and be isomorphic with other public organizations (DiMaggio and Powell, 1983). The institutional isomorphism is a useful concept for the organizations in which political and ceremonial culture is deeply rooted in organizational life, especially the public organizations in Indonesia (Abubakar, 2012). DiMaggio and Powell (1983) identified three isomorphism mechanisms, which are coercive, mimetic and normative isomorphism mechanisms.

\section{The Difficulties in Determining Performance Measurement}

The difficulties in determining performance measurement might result in incomplete or uninformative performance measurements which are required by the Government Performance and Result Acts (GPRA) (GAO, 1997). Therefore, the difficulties in determining the performance measurement led to the limitations in the use of performance measurements for the purpose of decision making and accountability (Astuti and Adiwibowo, 2011). According to DiMaggio and Powell (1983) when organizations began to experience environmental uncertainty, such as the difficulties in determining performance measurement, they were more likely to mimic other organizations. Consequently, they reflected mimetic isomorphism in government institutions. Based on several theories and the arguments above, the following hypotheses were formulated:

$\mathrm{H}_{\mathrm{a}} \mathrm{a}$ : The difficulty in determining performance measurement has a negative impact on the development of the performance measurement systems.

$\mathrm{H} 1_{\mathrm{b}}$ : The difficulty in determining performance measurement has a negative impact on performance accountability.

$\mathrm{H} 1_{\mathrm{c}}$ : The difficulty in determining performance measurement has a negative impact on the use of the performance information.

\section{Training}

Training in making, implementing and using management accounting innovation enables organizations to clarify the correlation between new practices and organizational objectives (Shields, 1995; Cavalluzzo and Ittner, 2003; and Nurkhamid, 2008). This condition will result in a mechanism for government employees to understand, to accept and to feel comfortable with innovation, and to alleviate depressed feelings or confusion among the employees resulting from the implementation process. Therefore, it was necessary for the organizational personnel to prepare a strategic plan and performance report, (Renstra and Lakip), to determine program targets, to develop performance indicators for the program, to use program performance information in decision making, to relate the performance of a policy/program/activity to the achievement of the organizational objectives (Cavalluzzo and Ittner, 2003), including the training to design and to implement the performance indicators (Tucker and Willoughby, 2002).

Organizational personnel who had a technical understanding and capability related to the implementation of the performance measurement system, would be able to successfully implement the performance measurement system (The Urban Institute, 2002). The technical capability was required to analyze data, to present performance reports in a form that was easy to 
understand, and to prepare particular reports in accordance with stakeholders' characteristics (Nurkhamid, 2008).

The training for the organizational personnel also improved the communication among divisions and departments about public services, performance, and performance measurement. The number of personnel who are able to understand the performance measurement process both quantitatively and qualitatively has an impact on the materialization of performance accountability (Artley, 2001) and the use of the performance information (The Urban Institute, 2002 in Nurkhamid, 2008). The training emerged from organization professionals so that it reflected the normative isomorphism in government institutions. Based on the several theories and arguments above, the following hypotheses were formulated:

$\mathrm{H} 2_{\mathrm{a}}$ : Training has a positive impact on the development of performance measurement systems.

$\mathrm{H} 2_{\mathrm{b}}$ : Training has a positive impact on performance accountability.

$\mathrm{H} 2_{\mathrm{c}}$ : Training has a positive impact on the use of performance information.

\section{Top Management Commitment}

Management is a part of all organizations, and it means that the management commitment represents the emotional attachment of individuals in the management of an organization to be involved in the effort to complete its missions, the values and the objectives of the organizations. In other words, the management commitment is a more concrete form of loyalty, to see the extent to which the management pays careful attention to, contributes ideas to, and is responsible for, the efforts to meet the objectives of the organizations. Organizations with strong top management commitments from their leaders and followers are more likely to easily meet their objectives, and have better performance, as compared to the ones without any top management commitment (Astuti and Adiwibowo, 2011). Thus, a strong top management commitment is required by an organization to improve its performance accountability (Artley, 2001) and to better use the resulting performance information (The Urban Institute, 2002). Top management commitment emerges from individual professionalism that is reflected in the normative isomorphism of government institutions. Based on the theories and arguments above, the following hypotheses were formulated:

$\mathrm{H} 3_{\mathrm{a}}$ : Top management commitment has a positive impact on the development of performance measurement systems.

$\mathrm{H} 3_{\mathrm{b}}$ : Top management commitment has a positive impact on performance accountability.

$\mathrm{H} 3_{\mathrm{c}}$ : Top management commitment has a positive impact on the use of performance information.

\section{Innovation}

Attitude, as an innovation measurer, represents a pattern of basic assumptions that are found, created or developed by certain groups for the purpose of organizational learning to solve problems resulting from external adaptation or internal integration that have been good enough, and hence it is necessary to teach new members the correct method to understand, to think of and to feel the various problems (Schein, 1992 in Julnes and Holzer, 2001). Of course, the performance measurement results in organizational change. The change will be perceived in different ways by individuals in the organization and it will cause organizational culture changes (Sihaholo and Halim, 2005). Innovation emerges from individual professionalism which reflects the normative isomorphism in government institutions. Based on the theories and arguments above, the following hypotheses were formulated:

$\mathrm{H} 4_{\mathrm{a}}$ : Innovation has a positive impact on the development of performance measurement systems.

$\mathrm{H} 4_{b}$ : Innovation has a positive impact on performance accountability.

$\mathrm{H} 4_{\mathrm{c}}$ : Innovation has a positive impact on the use of performance information. 


\section{Incentive}

Kloot (1999) indicated that good performance indicators for both organizational units and individuals may be used on a reward and punishment basis. Verbeeten (2008) suggested that incentive had a positive and significant impact on performance. Indudewi and Nafasita (2012) suggested that essentially individuals had an interest in improving their prosperity, that incentives represented a fundamental factor in improving and controlling their performance. It emerged from organizational policies for good individual performers in organizations, and it reflected the normative isomorphism in government institutions. Based on these theories and arguments above, the following hypotheses were formulated:

$\mathrm{H} 5_{\mathrm{a}}$ : Incentive has a positive impact on the development of performance measurement systems.

$\mathrm{H} 5_{\mathrm{b}}$ : Incentive has a positive impact on performance accountability.

$\mathrm{H} 5_{\mathrm{c}}$ : Incentive has a positive impact on the use of performance information.

\section{Information System Limitation}

Some results of prior studies into the performance of the public sector also indicated that the problems in information systems posed the main obstacles to gaining success in the implementation of a performance measurement system. Cavalluzo and Ittner (2003) and Nurkhamid (2008) confirmed that the problems in the information system related to the limitations of the information system's capability to provide reliable, valid and timely data at an effective cost. Previous research findings by Cravcuk and Schank (1996) indicated that government institutions often faced serious problems in measuring performance because of the problems in the information system, such as the difference in the definition of data, technology, ease of access, and the amount of collected data. According to DiMaggio and Powell (1983), when organizations experienced environmental uncertainty such as information system limitations, they were more likely to mimic other organizations.
Therefore it reflected mimetic isomorphism in the government institutions. Artley (2001) and The Urban Institute (2002) suggested that the availability of the report of the performance information would improve performance accountability and the use of performance information in decision making. Based on the various theories and arguments above, the following hypotheses were formulated:

H6a: Information system limitations have a negative impact on the development of performance measurement systems.

$\mathrm{H6}_{\mathrm{b}}$ : Information system limitations have a negative impact on performance accountability.

H6 $6_{c}$ : Information system limitations have a negative impact on the use of performance information.

\section{Decision Making Authority}

According to Astuti and Adiwibowo (2011), it is possible for an organization to delegate the authority for decision making from superiors to subordinates. The delegation of the authority for decision making helps the management make decisions more quickly, and improves creativity and the effort to make changes. Additionally, it also improves the accountability among personnel of public sector organizations. Each of the subordinates is given the authority for decision making and they have to be responsible for the decisions they make to meet the predetermined goals.

The involvement of program staff in the development of a performance measurement system is one of the factors influencing the use of performance information in an organization (The Urban Institute, 2002), while the authority for decision making is also a factor that influences the materialization of performance accountability (Artley, 2001). Managers believe that the implementation of the measurement system will support their decision making activities, and hence they are more motivated to implement and to use the performance measurement. On the contrary, managers who are lacking in authority do not have any reason to 
accept the system (Nurkhamid, 2008). The decision making authority emerges from individual professionalism that is reflected in the normative isomorphism of government institutions. Based on the theories and arguments above, the following hypotheses were formulated:

$\mathrm{H} 7_{\mathrm{a}}$ : Decision making authority has a positive impact on the development of performance measurement systems.

$\mathrm{H}_{\mathrm{b}}$ : Decision making authority has a positive impact on performance accountability.

$\mathrm{H} 7_{\mathrm{c}}$ : Decision making authority has a positive impact on the use of performance information.

\section{RESEARCH METHOD}

\section{Data Collection Technique}

The data in the study were primary data collected using the mixed method. The mixed method combined qualitative and quantitative approaches (e.g., using the perspective of qualitative and quantitative, data collection, analysis and inferential techniques) to obtain the comprehensiveness and depth of understanding, and the confirming evidence (Johnson et al, 2007). The strategy of the mixed method was applied by using an explanatory sequential approach. The explanatory sequential approach was the strategy of the mixed method that offered quantitative data analysis using questionnaires for the first stage, and then proposed qualitative data analysis using interviews in the second stage, which referred to the initial results of the quantitative stage (Creswell, 2010). The objective of all of the strategies was to use the qualitative results to explain the initial quantitative results (Creswell and Plano Clark, 2011). Therefore, the first data collection method of the study was a survey using a questionnaire that was given directly to the chosen respondents, followed up with faceto-face interviews with the respondents.

\section{Samples and Population}

The population of the study was the Government of the Special Region of Yogyakarta, the Government of Sleman District, the Gov- ernment of Bantul District, the Government of Gunung Kidul District, the Government of Kulonprogo District, and the Government of Yogyakarta City. The sampling method was a purposive sampling. The criterion of the sampling was a government employee with a minimum position of echelon four, with at least a year of formal work in agencies/bodies/offices, who considered that their working period had provided them with the opportunity to be involved in and responsible for the process of strategic planning and performance reporting and hence believed that they understood the situation and the condition of their organization and environment (Sihaholo and Halim, 2005; Putra, 2006; Nurkhamid, 2008; Astuti and Adiwibowo, 2011; Wijaya and Akbar, 2012).

\section{Variable Operational Definitions and Varia- ble Measurement}

a) Independent Variables

Difficulties in Determining Performance Measurement. The variable uncovered the problem level in defining and interpreting performance measurement in an organization. This variable was measured using an instrument based on the research questions by Cavalluzzo and Ittner (2003) and as also used by Putra (2006), Nurkhamid (2008), Yowi (2011), and Akbar (2012).

Training. The variable uncovered the training level given by an organization to its personnel, related to the implementation of performance measurement. This variable was measured using an instrument based on the research questions of Cavalluzzo and Ittner (2003) which were also used by Putra (2006), Nurkhamid (2008) and Yowi (2011).

Top Management Commitment. The variable measured the commitment level of the leaders to achieve results through performance measurement. This variable was measured using an instrument based on the research questions of Cavalluzzo and Ittner (2003) and also used by Putra (2006), Nurkhamid (2008), Yowi (2011), and Akbar (2012). 
Innovation. The variable showed the attitude of leaders and their staff towards change (i.e., innovation). This variable was measured using an instrument based on the research questions of Julnes and Holzer (2001) and also used by Sihaholo and Halim (2005) and Nurkhamid (2008).

Incentive. This was the policy made by an organization as a response to innovation as risk taking activities, measured on the basis of the respondents' responses to the presence of rewards/incentives in an organization, for the effort to improve organizational performance and the risk taking, in an organization in the form of innovative ideas to improve organizational performance. This variable was measured using an instrument based on the research questions of Julnes and Holzer (2001) and also used by Sihaholo and Halim (2005) and Nurkhamid (2008).

Information System Limitations. The variable uncovered the limitations of the information system capabilities of an organization to provide valid, reliable and timely data. This variable was measured using an instrument based on the research questions of Cavalluzzo and Ittner (2003) and was also used by Putra (2006), Nurkhamid (2008), Yowi (2011).

Decision Making Authority. The variable uncovered the authority level in decision making based on performance information, which was delegated by the organization to its personnel to support the achievement of the organization's strategic objectives. This variable was measured using questions based on the research instruments of Putra (2006) and Yowi (2011).

\section{b) Dependent Variables}

The Development of the Performance Measurement System. The variable indicated the effort of an organization to develop a performance measurement system as reflected in the determination and the establishment of, various types of performance measurements that were result-oriented, for various policies/programs/ activities it organized. This variable was measured using an instrument based on the research questions of Cavalluzzo and Ittner (2003) which had also been used by Putra (2006), Nurkhamid (2008), Yowi (2011).

Performance Accountability. The variable measured the extent to which the leaders were responsible for achieving the results of the policies/programs/activities organized by their organization. This variable was measured using an instrument based on the research questions of Cavalluzzo and Ittner (2003) and also used by Putra (2006), Nurkhamid (2008), Yowi (2011) and Akbar (2012).

The Use of Performance Information. The variable indicated the various kinds of use of performance information to support the decision making in an organization. This variable was measured using an instrument based on the research questions of Cavalluzzo and Ittner (2003) and was also used by Putra (2006), Nurkhamid (2008), Yowi (2011) and Akbar (2012).

The variables in the study were measured by a Likert Scale from 1 (highly disagree) to 5 (highly agree), except for the training variable, which was measured using yes (1) or no (0) questions.

\section{Data Analysis Method}

\section{Quantitative Approach}

The quantitative approach of the study used a Partial Least Square (PLS) analysis to test the hypotheses. The PLS analysis was a multivariate statistic technique that compared multiple dependent variables to multiple independent variables. The PLS was one of the variant-based Structural Equation Modeling (SEM) statistical methods that were able to simultaneously test the measurement model and the structural model (Hartono, 2011). It was a quality predicting tool used to develop theories (Hartono and Abdillah, 2009). Therefore, the PLS fitted the study because it combined complex models, and used a relatively small number of samples to anticipate the low response rate of the samples in the targeted local governments. The study used SmartPLS (Version 2.0M3) developed by Ringle, Wende and Will that was downloaded from http://www.smartpls.de. 


\section{Qualitative Approach}

The qualitative data analysis in the study was made using a thematic analysis. The thematic analysis was a qualitative analysis method to identify, analyze, and to report patterns (themes) found in the data (Braun and Clarke, 2006). Subsequently, more detailed analysis was made using a coding process. The sorted data resulting from the interviews were related to the themes or the problems of the study. And then, the interview results were interpreted in the description of the results (Creswell and Plano Clark, 2011).

\section{RESULTS}

\section{Quantitative Approach}

\section{a. Pilot Study}

The respondents of the pilot study were 30 individuals consisting of 15 local government employees who were studying in the master's degree program in Development Economics at Universitas Gadjah Mada Yogyakarta and 15 local government employees who were studying in the science master's degree program of Universitas Gadjah Mada majoring in Development Economics. The analysis of the results of the pilot study was made using the software of SmartPLS ver. 2.0M3.

The results of the pilot study showed that all of the constructs had passed the validity test (i.e., AVE and communality value $\geq 0.5$ ) and the reliability test (i.e., Cronbach's alpha and composite reliability $\geq 0.7$ ). The results of the pilot study showed that the loading factor value was $>0.6$ and based on the cross-loading table it could be concluded that considering each of the indicators of a latent variable, (i.e. constructs) the highest value was found in the targeted construct, as compared to the value in other constructs. This indicated that the questions in the study were valid and reliable for real study.

\section{b. Quantitative Data Collection}

Quantitative data was collected by distributing questionnaires to 288 respondents in the Special Region of Yogyakarta. There were 247 questionnaires returned, but not all of them could be analyzed because some of the question- naires were incomplete. Thus, the resulting number of questionnaires eligible for analysis was 214 , as illustrated in the respondent profile summarized in Table 1 below.

\section{c. Demography Analysis}

Demographic analysis might provide an additional explanation of the study results. The correlation between the demographic variables and the development of the performance measurement system, the performance accountability and the use of performance information was summarized in Table 2. The demographic analysis was made using ANOVA and the results showed that the variables of age, the working period and present position in the performance accountability had significant value, thus indicating that age, the working period and present position had a significant impact on local government performance.

\section{d. Data Range}

Based on the results of the data processing of the 214 respondents, 57 items were considered to be valid in the theoretical range between minimum 2 and maximum 65 . All of the responses of the respondents involved in the actual range were in their theoretical range, which was minimum 2 and maximum 65 , so that it might be said that in general the responses of the respondents were in their theoretical range.

\section{e. Non-response Bias}

The non-response bias was the bias caused by the respondents returning with belated responses (Hartono, 2011a). The author of the study divided the possibility of the non-response bias into two, which were the non-response bias based on the time of the Mann-Whitney U-test, and the location bias tested using the KruskalWallis H-test. The statistical instrument to test the non-response bias was SPSS version 18.

The results of the Mann-Whitney U-test were obtained on the basis of the differences in the time taken to return the questionnaire. They showed that there were not any significant differences between the respondents returning the questionnaires in the first collection stage, and those returning the questionnaires in the second 
collection stage, at the statistical significance above 0.05 . The results of the Kruskal-Wallis Htest showed that there were not any differences in the responses of the respondents in the 6 sample areas of the study at the statistical significance above 0.05 .

Table 2. The Summary of the Correlation of Demographic Variables with the Development of Performance Measurement System, the Performance Accountability and the Use of Performance Information

\begin{tabular}{lccc}
\hline \multicolumn{1}{c}{$\begin{array}{c}\text { Demographic } \\
\text { Variables }\end{array}$} & \multicolumn{3}{c}{ Sig } \\
\cline { 2 - 4 } & DPMS & PA & UPI \\
\hline Age & 0.241 & 0.020 & 0.971 \\
Education & 0.880 & 0.178 & 0.900 \\
Length of service & 0.694 & 0.000 & 0.512 \\
Gender & 0.201 & 0.382 & 0.139 \\
Current Position & 0.222 & 0.035 & 0.821 \\
\hline
\end{tabular}

Source: Output SPSS, 2013

\section{f. Quantitative Data Analysis and Hypotheses Test}

The results of the evaluation of the measurement model (path analysis) using a PLS algorithm iteration showed that all of the construct indicators passed the convergent validity tests, which was AVE and communality, with the value above 0.5 (see Table 3 ). The discriminant validity test was the cross loading factors indicating that each of the indicators in a construct of the measurement model had met the discriminant validity requirement, because each of the indicators in a construct differed from those in the other construct and grouped in the construct with the score of $>0.6$. Table 3 also showed that all of the constructs met Cronbach's Alpha and Composite Reliability $>0.6$.

The evaluation of the structural model in Table 3 gave the $\mathrm{R}^{2}$ value for the PA construct of 97.07 percent, the $\mathrm{R}^{2}$ value for the DPMS construct of 19.67 percent, and the $\mathrm{R}^{2}$ value for the UPI construct of 54.55 percent. Hypotheses tests were carried out by comparing T-table and $\mathrm{T}$-statistic values resulting from a bootstrapping process. If the T-statistics value was higher than the T-table value, the hypothesis was confirmed and vice versa. At the confidence level of 95 percent (alpha 5 percent), the T-table value for hypotheses of a tail was $\geq 1,64$ (Hair et al., 2006, Hartono, 2009).

Twenty one hypotheses were tested and 16 hypotheses were statistically confirmed because their T-statistics values were higher than their Ttable. The 16 hypotheses were H1c (DDPM $\rightarrow$ UPI: $\gamma 3=-0.170141, t=3,897843) ; \mathrm{H} 2 \mathrm{a}(\mathrm{T} \rightarrow$ DPMS: $\gamma 4=-0.120234, t=1.661271) ; \mathrm{H} 2 \mathrm{~b}$ $(\mathrm{T} \rightarrow \mathrm{PA}: \quad \gamma 5=0.034536, \quad t=2.635693) ; \quad \mathrm{H} 2 \mathrm{c}$ $(\mathrm{T} \rightarrow \mathrm{UPI}: \gamma 6=-0.179524, t=3.514174) ; \mathrm{H} 3 \mathrm{~b}$ $(\mathrm{TMC} \rightarrow \mathrm{PA}: \gamma 8=1.263029, t=5.180138) ; \mathrm{H} 3 \mathrm{c}$ $(\mathrm{TMC} \rightarrow$ UPI: $\gamma 9=-1.665029, t=7.043097) ; \mathrm{H} 4 \mathrm{a}$ $(\mathrm{IV} \rightarrow$ DPMS: $\gamma 10=0.767806, t=1.901311) ; \mathrm{H} 4 \mathrm{c}$ $(\mathrm{IV} \rightarrow$ UPI: $\gamma 12=1.821218, t=9.893432)$; H5a $(\mathrm{IC} \rightarrow$ DPMS: $\quad \gamma 13=-0.341692, \quad t=2.441043)$; H5b (IC $\rightarrow$ PA: $\gamma 14=-0.447488, t=4.224462)$; H5c (IC $\rightarrow$ UPI: $\gamma 15=-0.405046, t=3.321745$ ); H6b (ISL $\rightarrow$ PA: $\gamma 17=0.021724, t=2.249855$ ); H6c (ISL $\rightarrow$ UPI: $\gamma 18=-0.359847, t=7.509086$ ); H7a $\quad$ (DMA $\rightarrow$ DPMS: $\quad \gamma 19=0.311418, \quad t=$ 7.141906); H7b (DMA $\rightarrow$ PA: $\gamma 20=-0.045981$, $t=2.869588)$; H7c (DMA $\rightarrow$ UPI: $\gamma 21=0.382927$, $t=8.728015)$.

Five hypotheses were not confirmed statistically because their T-statistics values were lower than their T-table values. The five hypotheses were H1a (DDPM $\rightarrow$ DPMS: $\gamma 1=-0.066871, t=$ $0.71322)$; H1b (DDPM $\rightarrow$ PA: $\gamma 2=-0.003955, t=$ 0.395555); H3a (TMC $\rightarrow$ DPMS: $\gamma 7=-0.35438$, $t=0.709163)$; H4b (IV $\rightarrow$ PA: $\gamma 11=0.161743, t=$ 0.89006); H6a (ISL $\rightarrow$ DPMS: $0.028519, \quad t=$ 0.375982).

\section{Qualitative Approach}

\section{a. Qualitative Data Collection}

It was clearly observed in Figure 1 that there were 5 outlier respondents, but as they were not available for interview, the study used non-outlier respondents to catch the existing isomorphism phenomena. The respondents also filled in the availability for interview form enclosed in with the questionnaire for the survey, and they confirmed their availability for interview when the author contacted them. The respondents were also selected on the basis of the areas in the study to represent the population. 
Table 3. Iteration Algorithm

\begin{tabular}{lllllll}
\hline & \multicolumn{2}{c}{ Validity Test } & & \multicolumn{2}{c}{ Reliability Test } & \\
\cline { 2 - 3 } \cline { 5 - 6 } & AVE & Communality & & $\begin{array}{c}\text { Composite } \\
\text { Reliability }\end{array}$ & $\begin{array}{c}\text { Cronbach's } \\
\text { Alpha }\end{array}$ & R Square \\
\hline PA & 0.952909 & 0.952909 & & 0.987787 & 0.983264 & 0.97074 \\
IV & 0.95546 & 0.95546 & & 0.988472 & 0.984226 & \\
IC & 0.96499 & 0.96499 & & 0.982183 & 0.963834 & \\
TMC & 0.678302 & 0.678302 & & 0.926361 & 0.907793 & \\
DDPM & 0.617249 & 0.617248 & & 0.86371 & 0.786615 & \\
ISL & 0.903397 & 0.903397 & & 0.986803 & 0.984673 & \\
DMA & 0.723928 & 0.723928 & & 0.939959 & 0.922686 & \\
T & 0.683029 & 0.683028 & & 0.914165 & 0.882016 & \\
DPMS & 0.822667 & 0.822667 & & 0.958661 & 0.946184 & 0.196738 \\
UPI & 0.64668 & 0.64668 & & 0.95948 & 0.954237 & 0.545525 \\
\hline
\end{tabular}

Source: Output SmartPLS ver 2.0 M3, 2013



Figure 1. The Scatter Plot of Respondents Data Processing

According to Creswell (2010), interviews might be organized either as face-to-face, or over the telephone or in a focus group, and via an internet interview using email or any other online programs. The interviews in this study were organized as face-to-face with 5 respondents and an email interview with one respondent from SKPD Gunung Kidul. The interviews took about 15-20 minutes. The author recorded the interviews using an audio recorder, having first asked the respondents for permission to record each interview.

\section{b. Qualitative Data Analysis}

Based on the interviews with the selected respondents, it was concluded that the difficulties in determining performance measurement did not have any significant impact on the de- 
velopment of performance measurement systems and performance accountability, but did have a significant impact on the use of performance information in the SKPD of the Special Region of Yogyakarta. The employees of the local government of the Special Region of Yogyakarta did not face any problems in determining performance measurement because there has been a LAKIP form available to them, in particular containing technical guidelines (Juknis) and referred to the RPJMD (Rencana Pembangunan Jangka Menengah Daerah), the local medium term development plan. It was confirmed by the following respondent's statement:

"There is not any problem in determining indicators and some of our indicators are in accordance with minimal service standards (Standar Pelayanan Minimal) and there are also particular technical guidelines. And then, we scrutinize the existing operational definition and there is not any problem in the implementation and we find out whether the targets are met or not."

(Head of the Data and Information Section of Bantul District Health Office)

Though the SKPDs in the Special Region of Yogyakarta did not have any problem in determining the performance measurements, they faced problems in the use of performance information. This was confirmed by the following respondent's statement:

"There is not any problem in determining performance measurements because the performance measurements in preparing the LAKIP had been standardized in the existing LAKIP form. The problem is that the LAKIP form has not reflected the real performance and indicates only the financial performance. However, the LAKI preparation contains the target achievements that are evaluated with various indicators and the results of programs/activities."

(Head of the Subsection of the Public Works Office of Gunung Kidul District)

Based on the results of the content analysis of the interview transcript with the respondents, it could be concluded that the mimetic isomor- phism phenomena took place in the SKPDs of the Special Region of Yogyakarta.

Based on the interviews with the respondents, it was evident that training had a positive impact on the development of the performance measurement system, the performance accountability and the use of performance information in the SKPDs of the Special Region of Yogyakarta. It helped the employees of the local government of the Special Region of Yogyakarta to prepare the strategic plan, determine performance objectives for a program/activity/project, develop various performance indicators for a program/ activity/project, use performance information in the decision making process and relate the achievement of the performance of a program/ activity/project to the existing organizational objectives. It was confirmed by the following respondent's statement:

"There has been training. In general, all of the friends of the program, those from the inspectorate invite us, also those from the agency for regional development (BAPPEDA) sometimes invite us. We are invited by some participants to get involved in an activity/training so that we will be able to prepare the LAKIP in accordance with the particular program."

(Head of the Metal Industry Department of Disperindagkop of the Special Region of Yogyakarta)

Based on the results of the content analysis of the interview transcripts with the respondents it could be concluded that the normative isomorphism phenomena took place in the SKPDs of the Special Region of Yogyakarta.

Based on the interviews, the top management's commitment did not have any significant impact on the development of the performance measurement system, but it had a significant impact on the performance accountability and the use of performance information in the SKPDs in the Special Regional of Yogyakarta. The employees of the local government of the Special District of Yogyakarta had the commitment to prepare the LAKIP, but there were some ob- 
stacles, such as the availability of accurate data. What follows was a respondent's statement:

"The commitment is high enough. It is manifested in the seriousness to prepare as good a LAKIP as possible, so that the LAKIP can reflect the description of the real $S K P D$ 's performance. The difficulties are found more in technical matters such as the need for accurate and face data."

(Head of the Public Works Office of Gunung Kidul District)

Though there were obstacles in accomplishing the commitment, the employees of the local government of the Special Region of Yogyakarta prepared the LAKIP because it might be used for the evaluation of the performance of the SKPDs. The following was a respondent's statement:

"The LAKIP enables us to reflect on our performance especially in a year. I think it is important to evaluate our performance for a year to improve the programs and the activities we organize."

(Head of the Sub-section of Planning and Evaluation of Diskanertrans of Kulonprogo District)

Based on the content analysis of the interview transcripts with the respondents, it could be concluded that the normative isomorphism took place in the SKPDs of the Special Region of Yogyakarta.

Based on the interviews with the selected respondents, it was evident that innovation had a positive impact on the development of the performance measurement system and the use of performance information. However, it did not have any significant impact on the performance accountability of the SKPDs in the Special Region of Yogyakarta. The employees of the local government of the Special Region of Yogyakarta always innovated to improve their organizational performance. This was confirmed by the following respondent's statement:

"We always coordinate, but we present data that is sometimes incomplete and its parameters are not optimal. And finally, we innovate something to reflect the performance on the budget. So, it does not indicate that the budget is not $100 \%$ absorbed and the performance was not $100 \%$ physically. Because saving also represents a part of performance, the budget of 100 million and 99 million are absorbed and the physical result is $100 \%$ means that it is an achievement, but sometimes people have different ways to see something."

(Head of the Metal Industry Department of Disperindagkop of the Special Region of Yogyakarta)

Based on the content analysis of the interview transcript with the respondent, it was concluded that the normative isomorphism phenomena took place in the SKPDs of the Special Region of Yogyakarta.

Based on the interviews with the selected respondents, it was evident that incentives had a positive impact on the development of the performance measurement system, performance accountability and the use of performance information in the SKPDs of the Special Region of Yogyakarta. The presence of an incentive would improve the performance of the employees of the local government of the Special Region of Yogyakarta. It was confirmed by the following respondent's statement:

"We refer to an incentive pattern, meaning that an employee gets a salary plus honorarium. As long as it is referred to as an activity, it is rewarded with a honorarium. The preparation of the LAKIP is also rewarded with a honorarium. So, it is expected that the incentive will improve their performance."

(Head of the Planning and Evaluation Subsection of the Agency of Regional Development (BAPPEDA) of Yogyakarta City)

Based on the results of the content analysis of the interview transcript with the respondents, it could be concluded that the normative isomorphism phenomena took place in the SKPDs of the Special Region of Yogyakarta.

Based on the interviews with the selected respondents, the information system limitation was not in evidence as having a negative impact on the development of the performance mea- 
surement system. However, it was evident that the information system limitation had a negative impact on the performance accountability and the use of performance information in the SKPDs of the Special Region of Yogyakarta. The information system limitation might be caused by inaccurate data, a lack of trust or the lack of timeliness. However, in practice the information system limitation of the SKPDs did not cause the tendency of the SKPDs to mimic other SKPDs. They overcame the information system limitation by sending confirmation to the data source and compiling the data in the internal SKPDs, though in practice there were still many limitations. This was confirmed by the following respondent's statement:

"When we compile the data, for example the data of economic growth/inflation and the calculation is conducted by BPS (Badan Pusat Statistik) and when their calculation is not logical we ask the data source to validate the data again and occasionally with minor changes."

(Head of the Economic Department of BAPPEDA of Sleman District)

The presence of the information system limitation had a significant impact on the performance accountability and the use of the performance information in the SKPDs. Therefore, it was necessary to use the data as the basis for the decision making process, and the lack of the complete, reliable and timely performance data could reduce the accountability of the employees of the local government to the parties concerned.

"The data on our database has not been optimal. The internal data exists, but the external one related to the performance of each of the areas has not been completed. For example, the data of industry is incomplete. We have 81,000 IKM and it is incomplete. What is the name? There are names, but incomplete. So, then we present only limited information such as the description of a company. The valid data is in the district/city and it is slowly updated. So, the recapitulation of the data in the district/city is not complete and the use of the data is also not optimal."

(Head of the Metal Industry Department of Disperindagkop of the Special Region of Yogyakarta)

Based on the content analysis of the interview transcripts with the selected respondents, it could be concluded that the mimetic isomorphism phenomena took place in the SKPDs of the Special Region of Yogyakarta.

Based on the interviews with the selected respondents, the decision making authority was proven to have a positive impact on the development of the performance measurement system, the performance accountability and the use of performance information in the SKPDs of the Special Region of Yogyakarta. The decision making authority represented the authority of a leader to make decisions. The employees of the local government of the Special Region of Yogyakarta had the authority in their respective areas, as regulated in the existing rules. The rules indicated the presence of external pressures, which was consistent with the following respondent's statement:

"First, it is indeed necessary for us to begin with a reference and the presence of the rules requiring us to prepare the LAKIP. I am in the planning department and we serve there as facilitators. Various materials come from the technical department and what we do is to prepare and to coordinate with the departments from which we collect the materials."

(Head of the Planning and Evaluation Subsection of Disnakertrans of Kulon Progo District)

When someone was given the authority to make decisions, or the right to make decisions, he or she was more likely to use the performance information in making the decision and it would increase his or her performance accountability. It was consistent with the following respondent's statement:

"The authority for preparing the LAKIP is with the LAKIP preparation team. As part of the team, each of the members has the right to give inputs and considerations in analyz- 
ing the performance of the SKPDs. The LAKIP is a performance report and hence the materials to prepare the report are discussed, especially the data of the conditions of performance achievement, including physical realization, financial/budgetary realization, and the achievement of targeted income, the achievement of the SKPDs' strategic plan targets that have been broken down into annual targets (RKT), and other targets whose indicators and values have been determined. So, the team authority is limited to the presentation of the data of the performance and to the analysis of the data as compared to the targets and to the conclusions of the condition of the SKPDs' performance. The bottom line is that the LAKIP preparation team only compares the targets and the realization of them and then draws conclusions as to whether their performance was as expected."

(Head of the Planning Sub-section of the Public Works Office of Gunung Kidul district)

Based on the results of the content analysis of the interview transcript of the selected respondents, it could be concluded that the coercive isomorphism phenomena took place in the SKPDs of the Special Region of Yogyakarta.

\section{CONCLUSION, IMPLICATION AND LIMITATION}

\section{Conclusion}

The study used two (2) study approaches, which were the quantitative and qualitative ones. Based on the results of the analysis with the quantitative approach, it was concluded that the study managed to prove that training, incentives and authority had positive impacts on the development of performance measurement systems, performance accountability and the use of performance information; difficulties in determining performance measurement had a positive impact on the use of performance information; top management commitment had a positive impact on performance accountability and the use of performance information; innovation had a positive impact on the development of performance measurement systems and the use of performance information; and information system limitations had a negative impact on performance accountability and the use of performance information.

The results of the qualitative analysis of the study indicated that training, top management commitment, innovation and incentives had a significant impact on the development of the performance measurement system, performance accountability and the use of performance information. They also corroborated the results of qualitative data processing and indicated that the actions taken by the SKPDs in the local government of the Special Region of Yogyakarta were motivated by normative isomorphism power. The results of the study showed that the authority to make decisions had a significant impact on the development of the performance measurement system, performance accountability and the use of performance information. They also corroborated the results of the quantitative data processing and indicated that the actions taken by the SKPDs in the local government of the Special Region of Yogyakarta were motivated by coercive isomorphism power.

\section{Implication}

The results of the study could contribute to the efforts by the employees of the local government of the Special Region of Yogyakarta to consider technical factors, including information system limitations and difficulties in determining performance measurements; organizational factors, including top managements' commitment, decision making authority, training and organizational culture factors, including innovation and incentives and demographic factors, including age, working period and present position in the context of isomorphism if they had to successfully implement effective performance measurements.

\section{Research Limitation and Recommendation for Future Research}

The study had some limitations that could influence its results. Firstly, it was limited only to 
technical factors, including information system limitations and the difficulties in determining performance measurements; organizational factors, including top managements' commitment, the decision making authority, training, and organizational culture, including innovation and incentives. Future studies might include other factors that influenced the performance measurement system such as rational factors, which were resources, objective orientation and external stipulations (Julnes and Holzer, 2001). Secondly, the difficulties in determining performance and the information system limitations in the study could not catch the phenomena of the presence of the actions taken because of mimetic motivation. Future studies might use other factors that could catch the isomorphism phenomena that influenced the performance measurement system. Thirdly, it was only conducted in the Special Region of Yogyakarta, so that it could not be generalized for the performance measurement practices in the whole of Indonesia. Future studies might broaden their objectives and included other local government institutions to improve the generalizability of their conclusions. Fourthly, it is highly recommended that future studies are reminded to use a mixed method because it would give a deeper understanding, and be able to test the results of the study with different approaches and to catch any isomorphism phenomena.

\section{REFERENCES}

Akbar, R., 2011. Performance Measurement and Accountability in Indonesian Local Government. Curtin University.

Akbar, R., R, Pilcher., and B, Perrin., 2012. "Performance Measurement in Indonesia: The Case of Local Government". Pacific Accounting Review, pp 262-291.

Artley, Will., 2001. The Performance Management Handbook Volume 3: Establisihing Accountability for Performance. USA: Performance- Based Management Special Interest Group (PBMSIG).

Astuti, R. T., and Adiwibowo, A. S., 2011. Persepsi terhadap Pengembangan Sistem
Pengukuran, Akuntabilitas, dan Penggunaan Informasi Kinerja di Instansi Pemerintah. http://www.eprint.undip.ac.id.

Braun, V., and Clarke, V., 2006. Using thematic analysis in psychology. Qualitative Research in Psychology, 3 (2). pp. 77-101. ISSN 1478-0887.

Cavalluzzo, K. S., and Ittner, Christopher. D., 2003. "Implementing Performance Measurement Innovations: Evidence from Government". Accounting, Organizations and Society, 29.

Creswell, John. W., 2010. Research Design Pendekatan Kualitatif, Kuantitatif, dan Mixed, edisi ketiga. Yogyakarta: Pustaka Pelajar.

Creswell, John. W., and Plano, Clark. Vicki. L., 2011. Designing and Conducting Mixed Methods Research. Sage.

DiMaggio, Paul. J., and Walter, W. Powell., 1983. "The iron cage revisited: Institutional isomorphism and collective rationality in organizational fields". American Sociological Review, 48, 147-60.

Effendi, Taufiq., 2006. Modul Indikator Kinerja. Kementerian Negara Pendayagunaan Aparatur Negara.

Fachruzzaman and Norman., 2010. "Implementasi Sistem Pengukuran Kinerja Satuan Kerja Perangkat Daerah (SKPD) di Kota Bengkulu”. Simposium Nasional Akuntansi XIII.

Gudono., 2012. Teori Organisasi. Yogyakarta: BPFE.

Hartono, Jogiyanto., 2011. Konsep dan Aplikasi Structural Equation Modeling Berbasiskan Varian dalam Penelitian Bisnis. Yogyakarta: STIM YKPN.

Hartono, Jogiyanto, and Abdillah, Willy., 2009. Konsep dan Aplikasi PLS (Patial Least Square) untuk Penelitian Empiris. Yogyakarta: BPFE.

Indudewi, Dian., and Nafasita, Febriana., 2012. "Pengaruh Sasaran Jelas dan Terukur, Insentif, Desentralisasi, dan Pengukuran Kinerja terhadap Kinerja Organisasi (Studi 
Empiris pada SKPD dan BUMD Kota Semarang)". Jurnal Dinamika Sosial Budaya, 14,1 .

Johnson, R. B., Onwuegbuzie, A. J., and Turner, L. A., 2007. "Toward a definition of mixed methods research". Journal of Mixed Methods Research, 1 (2), 112-133.

Julnes, Patria de Lancer., and Holzer, Marc., 2001. "Promoting the Utilization of Performance Measures in Public Organization: An Empirical Study of Factors Affecting Adoption and Implementation". Public Administration Review, 61 (6), 693 708.

Nurkhamid, M., 2008. "Implementasi Inovasi Sistem Pengukuran Kinerja Instansi Pemerintah". Jurnal Akuntansi Pemerintah, 3 (1), 45-76.

Putra, H. S., 2006. Pengaruh Faktor-Faktor Teknis dan Organisasi terhadap Pengembangan Pengukuran Kinerja pada Akuntabilitas Kinerja dan Penggunaan Informasi Kinerja Pemerintah Daerah. Thesis of Gadjah Mada University.

Republik Indonesia, Instruksi Presiden No. 7 tahun 1999 tentang Akuntabilitas Kinerja Instansi Pemerintah.

Ridha, M. Arsyadi., and Basuki, Hardo., 2012. "The Impact of External Pressure, Environmental Uncertainty, and Commitment of Management on Implementation of Financial Reporting Transparency". The Indonesian Journal of Accounting Research, 15 (2).

Scott, W. Richard., 1987. The Adolescence of Institutional Theory. Administrative Science Quarterly, 32, 493-511.

1995. Institutions and Organizations. Thousand Oaks, CA: Sage.
, 2004. Institutional Theory: Contributing to a Theoretical Research Program. Oxford UK: Oxford University Press.

Shields, M., 1995. "An empirical analysis of firm's implementation experiences with activity-based costing". Journal of Management Accounting Research, 7, 1-28.

Sihaholo, F. L., and Halim, A., 2005. "Pengaruh Faktor-Faktor Rasional, Politik dan Kultur Organisasi terhadap Pemanfaatan Informasi Kinerja Instansi Pemerintah Daerah". Simposium Nasional Akuntansi VIII. Solo, Indonesia, 15-16 September.

The Urban Institute., 2002. How and Why Nonprofits Use Outcome Information. Washington D.C: The Urban Institute.

Tucker, Laura., and Katherine. Willoughby., 2002. Use and The Effects of Using Performance Measures for Budgeting, Management, and Reporting. Case Study: Dekalb County, Georgia.

Villadsen, A. R., 2011. "Structural Embeddedness of Political Top Executives as Explanation of Policy Isomorphism". Journal of Public Administration Research and Theory. 21 (4).

Wijaya, A. C. H., and R. Akbar., 2012.” The Influences of Information, Goals and Objectives of Organization, and External Pressures towards the Use of Performance Measurement System in Public Sectors". AsiaAmerica-Africa-Australia (A4). Public Finance Management Conference. Surabaya, Indonesia, 13-14 November.

Yowi, Linda R. B., 2011. Hubungan FaktorFaktor Implementasi, Pengembangan Sistem, dan Hasil Sistem Pengukuran Kinerja. Thesis of Gadjah Mada University. 